\title{
Breaking Away from Progressive History: The Past and Politics in American Studies
}

Ari Helo

\section{(2) OpenEdition}

\section{Journals}

Electronic version

URL: https://journals.openedition.org/ejas/10263

DOI: 10.4000/ejas.10263

ISSN: 1991-9336

Publisher

European Association for American Studies

\section{Electronic reference}

Ari Helo, "Breaking Away from Progressive History: The Past and Politics in American Studies", European journal of American studies [Online], 9-1 | 2014, document 4, Online since 26 March 2014, connection on 08 July 2021. URL: http://journals.openedition.org/ejas/10263 ; DOI: https://doi.org/ 10.4000/ejas. 10263

This text was automatically generated on 8 July 2021.

Creative Commons License 


\title{
Breaking Away from Progressive History: The Past and Politics in American Studies
}

\author{
Ari Helo
}

\section{INTRODUCTION ${ }^{1}$}

1 This article suggests that, contrary to a widely shared view among American scholars, a progressive view of history is neither essential nor helpful to historical research in American studies-or in any other academic field. The idea of progress figures regularly in the notions of history that the highest American officials disseminate to the public. In his Inaugural Address of 2009 President Barack Obama spoke of "the quiet force of progress throughout our history" which he attributed to the "hard work and honesty, courage and fair play, tolerance and curiosity, loyalty and patriotism" of the American people. As to the here and now, he added that: "What is demanded is a return to these truths."2 Yet, progress that calls for a return is hardly progress in the sense of a genuine novelty entering the stage of history. Calling for a general revival of values seems more like an appeal to a cyclical view of history.

In his Second Inaugural, in 2005, President George W. Bush embraced opinions about history that were even more clear-cut. According to him, "History has an ebb and flow of justice, but history also has a visible direction, set by liberty and the author of liberty." ${ }^{3}$ Compared to what many professional historians would claim, both presidents appear to have a remarkably assured insight into history. While some historians occasionally embrace these kinds of notions, others shy away from viewing history in progressive terms, let alone from saying that history's direction is set by liberty. Very few would claim that history has a discernible direction. Least of all are professional historians likely to claim that there is one particular extra-human "author" of history, be s/he an author of liberty or of oppression or of something else. The author of history is always a historian. 
Where should one turn to find the origins of this presidential image of progressive history that has a "visible direction," but that still demands "a return" every now and then? Even before entering the Oval Office, President-elect Obama was attacked for his unwillingness to encourage any effort to subject the Bush administration to legal investigation. "We need to look forward as opposed to looking backwards" Obama stated. ${ }^{4}$ This classically progressive notion of looking forward rather than backward likewise does not sit well with his call for return. President Kennedy famously spoke about looking forward rather than backward. Thomas Jefferson argued that the Federalist "bigots in religion \& government" were men who held that "we are to look backwards instead of forwards for the improvement of the human mind." ${ }^{5}$ In 1800 , when Jefferson was elected third President of the United States, and his Democratic Republicans won the majority in both houses of the Congress, he proclaimed that "We can no longer say that there is nothing new under the sun." ${ }^{16}$ At least for Jefferson, history did not merely repeat itself.

But there is a problem here: this apparently core American preference for being forward-looking easily conflates politics with an intrinsically progressive view of history. If Bush and Obama share a belief in progressive history, how is it that they arrive at such different conclusions about the best policies of the future? In fact, hardcore conservatives are just as "future-oriented" as any self-described progressive, since they yearn for the revival of the olden times tomorrow. The politician's progress is always an attempt to gain control over the future, and there may or may not be ideological determinism involved in this. However useful the idea of progressive history may be to political leaders seeking to enact specific political agendas under the guise of obeying unchanging ideals, the idea is unfit for a historical research. All in all, the general commitment to human progress should be kept distinct from the discipline of history, which seeks knowledge of the past.

In what follows, I discuss some elemental aspects of the distinction between forwardlooking politics and the backward-looking discipline of history. In doing so I first focus on how a given idea may or may not be seen as developing in the course of time. I then show how fundamentally American political self-understanding evolves from Founding-era ideals. After that I point out some methodological problems inherent in the standard ideal of American Studies as an interdisciplinary field of study. Finally I suggest that if we are to achieve a more articulate understanding of the distinction between politics and history we need to set aside unnecessarily demonized notions of power and politics in the field of cultural studies. The thesis is simple: good historical research cannot arise from an intellectual commitment to progressive history. Let me emphasize at this early point that the scholars whom I attack-Joyce Appleby, Alan Trachtenberg, Gordon Wood, Michael Zuckert, and others-are also among those whom I appreciate most. My disagreements with them are about certain specific points and not about the general value of their works.

\section{IDEAS IN HISTORY}

6 Bruce Kuklick's famous 1972 critique of the so-called symbolic school of American Studies-represented by Henry Nash Smith, Leo Marx, and Alan Trachtenberg among others-took impulse from their apparently anachronistic history writing. He called it "presentism" by which he meant "interpreting the past in concepts applicable only to 
the present." ${ }^{17}$ According to Kuklick, these founders of American Studies too often saw their historical protagonists as anticipating a "coming fashion in thought and feeling." In Smith's Virgin Land (1951), for example, the grand idea of turning the desert into a garden appears "in embryo" in the works of numerous historical figures who were simply not yet ripe to express it fully. Smith appeared to argue that Carlyle anticipated a post-Freudian alienation in his writings, leading Kuklick to ask whether it is plausible to think that this famous writer, sitting at his desk, could really have thought something like "in this piece of writing I want to anticipate a post-Freudian version of alienation." ${ }^{8}$ The basic mistake, Kuklick contended, was in resorting to an essentially ahistorical view of one or another enduring grand idea as the focal point of American culture.

Whether or not Kuklick's critique is fully justified, it is notable that Smith's study definitely serves us well by making it utterly clear that the entry of the conquest of the Wild West into popular culture was concomitant with the conquest itself. As for Leo Marx's Machine in the Garden (1964), Kuklick finds the author making claims such as "The Tempest anticipates the moral geography of the American imagination." Drawing on Kuklick's critique, Howard Segal notes that Leo Marx's actual "historical" claim was that the entire pastoral ideal had turned into empty whining over spilled milk well before the turn of the twentieth century. Segal himself managed to find a number of much later, twentieth-century applications of the idea. ${ }^{9}$

What one should ask about such large-scale interpretations as Smith's or Marx's is whether an idea should be deemed one and the same when its manifestation has altered because (or regardless) of the constantly changing circumstances. This is the central problem in all historically oriented cultural studies. ${ }^{10}$ Let me next illustrate this problem by using the sacred notion of America's founding as a key example of how well-meaning, progressive ideas are sometimes misused in historical thinking.

9 To briefly return to Presidents Bush and Obama: they agree not only on the view that history speaks to progress but also on the significance of the Founders' legacy. "From the day of our Founding," President Bush asserted, "we have proclaimed that every man and woman on this earth has rights, and dignity, and matchless value" and "[a]dvancing these ideals is the mission that created our Nation." According to Obama, "Our Founding Fathers .... drafted a charter to assure the rule of law and the rights of man-a charter expanded by the blood of generations. Those ideals still light the world, and we will not give them up for expedience's sake."

10 As practically every American president -at least since Abraham Lincoln's Gettysburg Address-has called upon the ideals of the American founding, it is worth asking what series of events they are talking about. In a nutshell, the sacred notion of the founding consists of the founding generation first subscribing, by way of the 1776 Declaration of Independence, to the idea that all men are equal and endowed with the same natural rights and then incorporating that idea into the original Constitution of 1787 through its first ten amendments-ratified in 1791. This American Bill of Rights provided the nation with the assurance that the federal government would never restrict freedom of speech, freedom to assemble, or religious freedom. Hence, we have arrived at the seminal idea of America as a constitutionally, rather than politically, secured free society. This apolitical nature of the founding is its most celebrated aspect, as one may conclude from the fact that politicians so different as Bush and Obama can talk about it in exactly the same way. ${ }^{11}$ 
11 Indeed, even a cursory look at early American history writing conveys an oddly pejorative view of the notion of politics whenever the crucial issues of the founding era are at stake. The political theorist Judith Shklar, for example, once argued that under the Constitution "bargaining replaces the tumult of popular assemblies, as order and freedom are reconciled pre-politically." ${ }^{12}$ If order and freedom were reconciled prepolitically in the Constitution, how should one understand Thomas Jefferson's efforts to persuade James Madison to incorporate the bill of rights into it or his struggle with Hamilton and Adams over the right interpretation of the document? Were his attempts perhaps post-political in character?

12 On a closer look, Jefferson, the quintessential American high priest of minimal government, tends to appear as elementally indifferent to the very concept of politics. According to the historian Gordon Wood, the "Jeffersonian modern virtue" that "flowed from the citizen's participation in society, not in government" should be distinguished from "participation in politics." ${ }^{13}$ Jefferson's attitude looks distinctly modern in being antigovernment, if not entirely anti-political-as if "citizen participation in society" has nothing to do with the concept of politics.

13 In Joyce Appleby's legendary revisionist view of the Jeffersonian era, Capitalism and a New Social Order (1984), the forward-looking Jeffersonian liberals aimed at nothing less than a "retreat from politics." 14 The Jeffersonian vision of a free market society was to be realized to an extent that exceeded its original advocates' imagination. Those advocates, contrary to their own vision, not only remained slaveholders, but also failed to foresee the problems that their laissez-faire economic beliefs were bound to cause with the rise of monopoly capitalism by the end of the nineteenth century. In the final analysis, as champions of "a white male vision" only, the originators failed to realize that women's political rights comprise a logical element of the vision. ${ }^{15}$ Appleby's argument is simply that, even if the originators failed, American history realized the vision as it truly was.

14 Is this not close to arguing that there is an implicit American desire to realize the true Jeffersonian spirit and that every significant historical agent has somehow struggled to express it, no matter whether s/he managed to do so? In sum, Appleby can join the team of Henry Nash Smith, Leo Marx, and others, who find their protagonists constantly anticipating a "coming fashion in thought and feeling." 16

\section{THE IDEOLOGY OF ETERNAL RETURN}

15 There are more clearly ideological ways of arguing that American history is nothing but the gradual manifestation of the founding-era ideals. An illuminating example is Michael Zuckert's reading of the Declaration of Independence. In his interpretation, the whole message of the Declaration is derivable from a Lockean, pre-political notion of the universal rights of man. In effect, Zurckert's reading marginalizes all earlier and later historical developments as irrelevant to the true character of the American social contract that this sacred document allegedly embodies. We are offered a scheme that speaks of political experience but serves mainly to prove how little political history matters.

16 To make sense of this accusation, let me cite Zuckert's intriguing assertion that "the Declaration does not present literal or empirical history, but moral history." This purely conceptual history is grounded on a single truth that "all men are created 
equal." ${ }^{17}$ As for the origins of this truth, Zuckert draws on the familiar Lockean conception of the state of nature as prior to any imaginable social ordering between men. In delineating the "series of six truths" of the Declaration of Independence as a "kind of minihistorical narrative of the political experience of the human race," he offers us "three phases" of society and "the corresponding truths" in this form ${ }^{18}$ :

\begin{tabular}{|l|l|l|}
\hline Pre-political & All men are equal & $\begin{array}{l}\text { and endowed with certain } \\
\text { unalienable rights }\end{array}$ \\
\hline Political & $\begin{array}{l}\text { Governments are instituted to secure these } \\
\text { rights }\end{array}$ & $\begin{array}{l}\text { deriving their just powers from } \\
\text { consent of the governed }\end{array}$ \\
\hline Postpolitical & $\begin{array}{l}\text { If government becomes destructive of those } \\
\text { ends, there is a right to alter or abolish it }\end{array}$ & and institute new government \\
\hline
\end{tabular}

Zuckert concludes from this set of truths that "Neither God nor nature has established rule among human beings; they do this for themselves. Human beings, in other words, are not naturally political."19 People are, in essence, human rights possessors and therefore naturally equal. This is why all inequalities between them arise from artificial power structures.

The key to Zuckert's "narrative of the political experience of the human race" is not the evident linkage between the different phases of the political experience. Instead, the key is the correct ordering of the three truths: what lends meaning to the second, "political" phase is that it consists of people's common consent to the first, "prepolitical" truth that all men are equal. This is why the third truth, about instituting a new government, is categorized not as a political but as a "postpolitical" act. In other words, meaningful change in the Zuckertian "moral history" entails a revolution. Ordinary politics simply vanishes from this ethically charged narrative of the political experience, because any merely political change cannot bring about an essentially postpolitical revolution. Since the original social contract was settled in 1776, the rest of American history automatically loses its significance as anything other than a manifestation of that contract.

As for Zuckert's way of ordering the "self-evident truths," one must ask whether the founders got it right. In order to carry out his interpretation of the document Zuckert must criticize its wording. This is how he explicates the weak point: "The 'self-evident' truths about the altering or abolishing of government follow from the truths about the institution and ends of government, and therefore cannot be properly self-evident."20 The error, in Zuckert's view, is that the revolutionaries appeared to equate the Lockean truth of pre-political human equality with the right to alter or abolish any government, mistakenly seeing also the latter as self-evident rather than derivable from the former.

20 Neither the document nor Jefferson's original draft presents its "self-evident" (or "undeniable" as in the original draft) truths as apolitical. Another way to read the document is that governments were instituted to secure the equal rights of men, and that the problem lay in the revolutionaries' disagreement with the British about the means to preserve their rights. The document begins with their expressed wish to explain to "the candid world" their reasons to dissolve the governmental bonds with 
the British and establish their state governments anew. One may argue, therefore, that the revolutionaries' claim for independence was not developed in an apolitical vacuum of extra-historical truths. James Madison, for example, viewed the presumably prepolitical state of nature as nothing but sheer anarchy, "where the weaker individual is not secured against the violence of the stronger" and where "even the stronger individuals are prompted, by the uncertainty of their condition, to submit to government." ${ }^{21}$

In Zuckert's view, the Declaration of Independence provides us with a veritable "big bang" of the universe of politics proper, but only as a consequence of the pre-political human equality. Given that even the right to violent revolution is derivable from the Lockean pre-political phase, the middle category of the "political" cannot but represent a peaceful return to that same pre-political phase of unconditional human equality. Political history-as a sequence of such events as elections, debates, corruption scandals, changes of governments, and the like-is utterly meaningless compared to this grand notion of return. This is why Zuckert's category of politics has nothing to do with what people actually do in politics. It only reiterates their subscription to the first, pre-political Lockean truth. The only genuinely meaningful event that people encounter in the Zuckertian universe of political experience is the Lockean revolution.

Given that Zuckert seems to be a strict libertarian, equality for him consists of our essence as rights possessors and of nothing else besides. He argues, for example, that "no person who understands property as Jefferson does would accept a positive right to life." This allegedly Jeffersonian view of property rights is derivable from the first Lockean truth of equality only with the condition that we cannot interfere with each others' essence as property owners. In the final analysis, our fundamental moral obligation is that of non-interference, because "only a negative right to life can pass the test for becoming a right-in-the-proper-sense."22 Deep down, all morally relevant history consists of our continuing commitment to this libertarian truth of governmental non-interference. The obvious historiographical problem in Zuckert's scheme is that all human history prior to the American Revolution is diminished to a mere prehistory of "political experience," because the pre-political truth had not yet been grasped. Yet, any post-Revolutionary event appears equally dependent on this truth, and therefore equally insignificant. As implicated earlier, the "political" phase consists solely of the continuing manifestation of the first, pre-political truth.

The most far-reaching ideological implication of all this is that even a shift from the Bush administration to the Obama administration seems a mere change in the personnel of the government whose only task is the continuing manifestation of the great return to the pre-political phase of human equality. By the same token, everyday politics begins to seem as a pathetic struggle for nothing but governmental power, and politicians-who, as if by occupational hazard, tend to suggest new policies-begin to seem nothing but an alienated race of corrupt office seekers occupying the nation's capital. There is no way out of the Zuckertian conception of the politics of return, because nothing else is important enough to rival it. In sum, the fundamental flaw of this conception of politics is that one cannot discern any meaningful difference between the Bush and the Obama administrations' actual policies.

The Lockean social contract scheme seems a backward-looking rather than forwardlooking standard by which to explain meaningful changes in American history. Nevertheless, it is not regressive but "progressive" historians who tend to view the 
national grand narrative as an increasing manifestation of human equality. On may always construct that narrative upon such events as the emancipation of slaves, women's suffrage, the 1960s civil rights legislation, and Barack Obama's election to the presidency. Or consider Joseph J. Ellis's statement that "it was Lincoln's expansive revision of the original Jeffersonian version of natural rights philosophy that broadened the message to include blacks." ${ }^{23}$ Such a revision was hardly philosophical. Rather, the principle of human equality became nationalized in the sense that all male Americans were, at least in principle, given equal political rights. The 150 years of racial segregation that followed the Civil War was merely another sad interim, until the 1960s Civil Rights Movement brought about the next return to Locke's pre-political truth about human equality. How could women's struggle for equal suffrage fail to add further proof to this apparently inevitable American progress in manifesting the Lockean truth? In the historian Daniel Rodgers's apt summary, the Lockean-liberal school could nullify any other competing reading of American history by simply "raising the stakes of what counted as meaningful conflict, until every conceivable demonstration of conflict short of Jacobin or Bolshevist revolution vanished in the allpervasive liberal consensus." 24

Even progressive historians disagree on whether Theodore Roosevelt's initiatives for nation-wide health insurance should be viewed as a precursor of the health-care and welfare reforms advocated by Franklin D. Roosevelt, Lyndon B. Johnson, Bill Clinton, and Barack Obama. Responding to this challenge every historian-regardless of his/her own political views-necessarily encounters the question of what truly belongs to the sphere of allegedly "pre-political" human rights. Hence one must also encounter the historically variable notion of progress itself.

\section{HISTORY WRITING TODAY}

In his recent article, "American History in a Global Age," Johann M. Neem sees the task of national history as "constitutive of one's identity." Needless to say, globalization and identity building are the darling themes of American Studies as well as of Cultural Studies in general. Neem also thinks it evident that the "Founding Fathers thought that the nation must embody universal values." 25 But to what extent have Americans managed to clarify the content of these "universal values"? For example, in the Presidential elections of 2000, Al Gore's running mate Joseph Lieberman still asserted that the first Amendment of the Constitution has nothing to do with "the freedom from religion." 26

Two remarks are in place regarding Neem's attempt to link national history writing to the themes of globalization and identity formation. First, it is interesting that for many historians the long-declared death of the grand narrative does not seem to have anything to do with their commitment to the grand idea of globalization. The problems in adopting globalization as a common denominator of good history writing are similar to those that accompany the American founding. Any such criterion as multiculturalism may have an impact on what appears worth remembering. Do America's founding principles manifest themselves more, say, in the 1950s efforts to desegregate public education than in the policy of Virginia's Prince Edward County of shutting down all public schools in order to stop that process? Certainly, both sides of 
the controversy could rely on traditional notions of what it means to live up to the standards of the American founding.

Second, one might question whether the historian's contribution to a person's identity building is an appropriate criterion for serious historical research. Is identity equally important to every individual's self-determination? In theoretical literature the "primary identity" often appears alongside numerous "situational identities." ${ }^{27}$ It is worth asking, furthermore, whether a person cannot live quite comfortably in a moreor-less inarticulate "middle ground" between his/her everyday "role identities," say, as an American Studies scholar, as a Finnish university teacher, as a party member, as a parent, as a lover, as a coffeeholic, as an Elvis fan, and so forth.

Given this background, consider what kinds of tools for genuinely intercultural identity building American history may offer. The famous "Celadon" pamphlet, from 1785, has often been referred to as a summary of the Revolutionary generation's multicultural convictions. It spoke of the future America as divisible into "Nigrania," "Savagenia," "a French, a Spanish, a Dutch, an Irish, an English, \&c. yea, a Jewish state here in process of time" in terms of "all of them united in brotherly affection" and thus forming "the most potent empire on the face of earth." 28

Or consider the criteria by which an American Studies scholar might define constructive identity building. In her 2001 article "Welfare as Identity Politics" Jane Sherron De Hart makes the following argument: In addressing the problem of increasing intergenerational dependence on welfare among Americans, President Ronald Reagan drew on an image of the "welfare queen," but consciously refrained from bringing up the racial aspect of the issue. According to De Hart this was because "We all 'knew' she was black." What De Hart is doing here is criticizing a politician for merely being political. Her point is adequate on a much larger scale: What changed in American thought on welfare from the 1960s to the 1996 Welfare Reform Act was that for most politicians now "culture rather than structure was the problem."29

It is yet another question whether De Hart's attempt to contextualize this change in terms of ubiquitous nationalist ideas of ethnic citizenship helps one understand the change. Her argument that the immigration laws at the turn of the twentieth century were intended to "enhance the shared heritage of the national family" is dangerously close to the typical misconception that human equality in any politically relevant sense can be described by family metaphors. Modern democracy is by definition representative. Whole groups of people are still deprived of political equality even in America, beginning with children and the mentally ill. The innocents are excluded from the constituency; all those included remain responsible also for those excluded.

\section{METHODOLOGY AND CONTEXTUALIZATION}

The most common error in historically oriented American Studies research (as in other such disciplines) is the presumption that sheer common sense helps us in distinguishing valid historical interpretations from invalid ones. Common sense is a poor criterion. Quite commonplace patterns of thought sufficed to justify the Inquisition, the sixteenth-century religious wars, slavery in antebellum America, racial segregation, eugenics, the Holocaust, and the like. For a historian who takes it as selfevident that because of scientific progress our common-sense beliefs are of better 
quality than earlier ones, all this may appear quite unproblematic. Such a historian can always resort to the notion that the future generations will in any case re-write history. bankruptcy such a strategy opens the door for simple political disagreements among scholars. To give an example, when Joyce Appleby defended her view of Jefferson as a forefather of American liberalism against Lance Banning's interpretation of Jefferson as a classic, rather than a liberal republican, she eventually drew on the following maxim: "What remains to be resolved in the scholarly dispute about republicanism in America is whose republicanism we are talking about-that of the founding fathers or ours? And if theirs is ours, which one of ours?" ${ }^{30}$ This is an open call for turning history into a political dispute. It is much safer to say that neither the founders nor later generations ever had one common opinion about what American republicanism should look like. Serious historical research can never be based on the idea that we study such conceptions as eighteenth-century republicanism for our political purposes, as if history was not, like any other academic field, dedicated to seeking the truth, even if only about the past.

are dealing with the classic issue of contextualization here. In most cases, contextualization is a simple matter of agreeing or disagreeing with previous researchers about the general characteristics of the circumstances in which a given phenomenon occurred. Genuinely innovative interpretations tend to arise when a scholar chooses to characterize the very context anew. This is why such typical accusations that a given scholar has simply omitted "the political context proper" in his/her analysis are much more complicated than they first appear. ${ }^{31}$ Political discourse is often about the distinctions between what is truly natural and what is only arbitrary for human beings. Contextualization is the core issue of all methodological discretion, closely related to what Kuklick had in mind when talking about how Nash, Marx, and others view "great books as keys to the study of the cultures of which they are a part." 32

What can be explained about the American past is different from writing sweeping cultural portraits of it. Take for instance Trachtenberg's The Brooklyn Bridge (1965), which has been deemed a classic example of the interdisciplinary approach that American Studies should represent as an academic discipline. Trachtenberg begins his book with a detailed history of the building of the famous bridge in New York City in the late nineteenth century. Then he extends his perspective into a comprehensive study of a huge variety of symbolic uses of the bridge in art, in literature, and in conceptual American history. By the end of the book the bridge can be seen to symbolize almost anything typically American.

36 Can one justify the sort of methodological holism that Trachtenberg embraces? In associating this building project with larger trends of industrialization in the United States and those with even older trends in American thought, he ends up asserting that "American society followed Hamilton's course to manufacturing and capitalism" rather than Jefferson's course to agriculture. ${ }^{33}$ Are we supposed to conclude that Jefferson was an anti-capitalist thinker or that Hamilton discerned the genuinely meaningful aspects of America's future better than Jefferson? According to the author, Jefferson was also hostile to history, for his utopian model of yeomen's democracy "lay beyond logic: it was a dream of timeless harmony with nature." 34 Trachtenberg does not offer an explanation to what exactly "lay beyond logic" in the concept of timeless harmony. Was it not the founders' hope to achieve what all previous political theorists had failed to 
achieve, namely, a form of government that would stand the test of time? Whether Jefferson's intellectual outlook can be characterized as utopian is yet another question. 35

Be that as it may, the basic methodological question to be asked about Trachtenberg's book is this: How do his claims about the founders relate to other things that he does prove-say, about the building of the Brooklyn Bridge and about Crane's later poem about it? His literary analysis of the symbolic uses of the bridge answer entirely different questions about American culture than his case study of the history of American engineering. In fact, all research seeks to answer a specific kind of research question, and the chosen method determines the quality of the answer. The assumption is that at the very moment one takes up a question one has already chosen valid methods and excluded a number of other methods as invalid. Claiming that every method is part of some holistic whole of the methodological apparatus, would be to presume not only that knowledge is holistic, but also that reality must be so. Many philosophers would find such a notion amusing. The reason is that we do not know whether everything is related to everything else in any meaningful sense.

This is why history is best understood as an art seeking to explain a particular historical phenomenon in particular circumstances, not in a presumably coherent image of the past. Perhaps the past is not an entity to begin with. Even so, a historically oriented American Studies scholar may make valuable discoveries by crossing and revealing the apparently established categories of thought. The founding generation, for example, could not let go of the idea that the new ordering of society should be natural for human beings. This is precisely why they had to question a number of concepts drawn from the prevalent European model of society of orders as the only natural ordering of human society. Hence, we find Jefferson and Hamilton, for example, constantly politicizing a variety of old concepts and fighting over their new definitions while competing for power.

\section{POWER AND POLITICS}

Indeed, in order not to mistakenly depoliticize the past in the name of writing progressive rather than regressive history, we should let go of the unnecessarily demonized conception of power itself. Consider how Lawrence Grossberg characterizes one of the central tasks of Cultural Studies as examining "how power operates at different levels and infiltrates [!], contaminates [!] and limits [!] the possibilities that people have of living their lives in humane, dignified, and secure ways." ${ }^{36}$ This demonized image of power stems from a simple failure to see that power relations can always be questioned by politicizing them. ${ }^{37}$

Although power is by definition control over others, one may also view power relations as something that necessarily permeate our everyday life. A friend of mine told me that his recipe for a happy marriage is this: "I do as I am told and I like it." When walking my late dachshund, I used to be in a ceaseless contest for power with him on which route we should take, until I was trained how to be in control of my dear friend. As Dr. Bledsoe, the president of an African-American college in Ellison's Invisible Man, somewhat cynically remarked: "Power doesn't have to show off. Power is confident, self-assuring, self-starting and self-stopping, self-warming and self-justifying. When you have it, you know it. ... The only ones I even pretend to please are big white folks, 
and even those I control more than they control me." ${ }^{38}$ Power relations are immanent in human life, and should not be studied as a menace. Neither is there any reason to deem conflict inherently opposed to human sociability.

41 To be sure, our ubiquitous power struggles often lead to street violence, riots, rebellions, and wars. Politics, however, means conflict-solving with methods other than violence. The idea of politics as a public affair, in turn, rests on the view that the public leaves us to solve the conflicts of our private lives in the private sphere. Everything is not politics. Yet we constantly encounter situations in which authorities need to cross the line between the public and the private, as when it is deemed necessary to take children into foster care to protect them from their own parents. Or think of the heated 1970s busing debate about whether the authorities could demand that parents send their children to a far-away school in order to desegregate all schools in the area. In sum, everything is not political, but anything can be politicized.

Politicizing an issue means considering the power relations inherent in any societal norms. This is not to say that norms are nothing but power claims. But it does suggest that refusing to view them as power claims leads us to embrace easy conformism rather than critical thinking. By and large, the most well-established norms and patterns of behavior may begin to change only when they are politicized. Rioting often appears to bring such topics as racism and the excesses of global capitalism to the fore, but most often it conveys a lack of imagination of how to politicize an issue in a constructive way. In free democracy, one may always join a party, organize an ad-hoc group or sitins, found a journal, and so on.

As for our constant wavering between the public and the private spheres, the discussion about the rights of homosexuals is a good example. Homosexuality was politicized several times in the United States until the highest political leadership of the country recently decided to back the equal civil rights of homosexuals and lesbians. Homosexuals themselves first brought the topic to the public eye in the famous 1969 Stonewall Inn riots in New York City. They resisted their treatment as second-class citizens when it came simply to their right of assembly. In the early 1970s the San Francisco city fathers politicized the issue even further. In about a decade the timehonored medical definition of homosexuality as a mental disorder was done away with. ${ }^{39}$ As Andrew Sullivan has noted, handling the issue from the viewpoint of equality is not about propagating homosexuality. ${ }^{40}$ It is about giving due recognition to these people as human beings equal with all others.

What exactly was politicized in this process? It was the traditional understanding of normal sexual behavior, not the voting rights of homosexuals. By and large, homosexuals were not customarily hunted down in the "olden times" either. There had been ways of dealing with the issue so as to keep it out of the public eye. Most people were happy to live in ignorance in order to tolerate, a norm embodied in the now so suddenly bygone "don't ask, don't tell" policy of the U.S. armed forces. Entering the public sphere as homosexuals, these people questioned the erstwhile norm that such issues as sexuality and raising children belong to the private sphere only when the household includes a man and a woman. A lot of people became nervous, because their traditional understanding of normal intimate life appeared to be questioned, occasionally ridiculed.

It is important to ask what a given historical norm was truly like, even if it appears simply oppressive today. Women's right to vote was once another highly controversial 
subject. It took a lot of conscious lobbying and politicking until women's suffrage finally in 1919 began to manifest that silent force of progress in American history that President Obama speaks about. Or consider on what basis historian William Chafe can characterize the civil rights struggle of the 1960 s as "a social movement" that "compelled a political response" from "presidents in Washington D.C." ${ }^{41}$ Chafe talks of "national politics" as if politics were primarily something for which only the federal government can be held responsible, while the rest of America experiences "social" development. If the 1960s Civil Rights Movement does not count as political, what does?

\section{CONCLUSION}

Kucklick's central critique was that Nash, Marx, and others appeared too Platonic in their conviction that one could discern a given set of extra-historically important ideas simply developing in history. More recent efforts to posit identity formation, globalization, or some other grand idea as a new standard for good American history writing incur the same methodological problem. Any such standard is apt to turn history into a Manichean endeavor of detaching the good, so-called usable past from the apparently less important past characterized by easy conformism to the standards of the time. Hence, progressive history tends to omit rather than to recognize the significance of such facts as, say, that Jefferson remained a slaveholder for the whole of his life; that Lincoln swore to save the Union whether it demanded freeing all the slaves or freeing none; or that Wilson only reluctantly conceded to women's suffrage as a constitutional right.

Is all this to suggest that there is something wrong with the American idea? That depends solely on what one thinks the American idea is. One may promote equal access to education and health care with or without invoking the somewhat indeterminate founding-era ideals. Political action is always pursued from a forward-looking position in the present tense. That was also the position of Hamilton and Jefferson, who fought bitterly over the American future because they both knew that the past cannot be changed. By contrast, history is about explaining the human past as correctly as possible. Let it remain so.

\section{NOTES}

1. The author wishes to thank both Allan Megill and Niina Koskipää for their valuable editorial comments.

2. Barack Obama, Inaugural Speech, Jan 20, 2009, Website Miller Center, University of Virginia, Presidential Speech Archive as visited July 5, 2011 at http://millercenter.org/scripps/archive/ speeches/detail/4463.

3. George W. Bush, Second Inaugural Speech, Jan 20, 2005, in ibid. 
4. Quotation from Paul Krugman's column "Forgive and forget?" in International Herald Tribune, Jan. 17-18, 2009.

5. Thomas Jefferson to Joseph Priestley, Jan. 27, 1800 in Merrill D. Peterson, ed., Thomas Jefferson Writings (New York: Library of America), 1984, 1073.

6. Thomas Jefferson to Joseph Priestley, March 21, 1801, ibid., 1086.

7. Bruce Kuklick "Myth and Symbol in American Studies" (American Quarterly 24, 1972) in Lucy Maddox, ed., Locating American Studies: The Evolution of a Discipline (Baltimore: The Johns Hopkins University Press, 1999), 77.

8. Kuklick "Myth and Symbol in American Studies," 1999, 78.

9. Howard P. Segal "Commentary" in Maddox (ed.), Locating American Studies, 1999, 87-90. Let me add that I cannot quite understand Segal's accusation, for Marx explicitly refers to various modes of pastoralism of his own day at the very beginning of his book. Neither can I agree with Segal's insinuations that, contrary to the representatives of the symbolic school, such exemplary anthropologists as Victor Turner or Clifford Geertz "have surely done extensive fieldwork before reaching their conclusions." In my opinion Smith and Marx had studied their own, historical and literary material quite skilfully and creatively. (For the quotation, see ibid., 90.)

10. Notably, when Smith's Virgin Land appeared in 1951, it was appraised as a breakthrough in intellectual history, for the discipline of American studies had not yet been invented.

11. On this core notion of the founding myth, see also Ari Helo, Thomas Jefferson's Ethics and the Politics of Human Progress: The Morality of a Slaveholder (New York: Cambridge University Press, 2013), 7-11.

12. Quotation from Judith Shklar, "Montesquieu and the new republicanism," Machiavelli and Republicanism, ed. by Gisela Bock, Quentin Skinner and Maurizio Viroli (Cambridge: Cambridge University Press, 1990), 270 (Emphasis added).

13. Gordon Wood, "The Trials and Tribulations of Thomas Jefferson." in Peter S. Onuf (ed.), Jeffersonian Legacies (Charlottesville: University of Virginia Press, 1994), 406.

14. Joyce Appleby, Capitalism and a New Social Order: The Republican Vision of the 1790s (New York: New York University Press, 1984), 33.

15. Joyce Appleby, "Republicanism in Old and New Contexts" in The William and Mary Quarterly 43 $(1,1986), 33$; On this set of historiographical problems with Shklar, Wood, and Appleby, see also Helo, Thomas Jefferson's Ethics, 2013, 185-186n.

16. Kuklick, "Myth and Symbol" 1999, 78.

17. Michael P. Zuckert, The Natural Rights Republic: Studies in the Foundation of the American Political Tradition (Notre Dame: Univ. of Notre Dame Press, 1996), 18, 23. By clinging to this extrahistorical image of the human being Zuckert refutes both the republican thesis that we need a distinctly political notion of man and the communitarian thesis that we need a more socially oriented view of man (Ibid., 21).

18. Ibid., 18.

19. According to Zuckert's logic on this point, one may well ask whether human beings are naturally, say, eating creatures, given that they so often "do" even that "for themselves."

20. Ibid, p. 47.

21. James Madison, The Federalist Number 51, in Clinton Rossiter (ed.), The Federalist Papers by Alexander Hamilton, James Madison, and John Jay (New York: Penguin Books, 1961), 324.

22. Zuckert, Natural Rights Republic, 1996, 79. In fact, President Bush looked back further than to Locke when stating in his Inaugural Address that "When our founders declared a new order of the ages ... they were acting on an ancient hope that is meant to be fulfilled." Few historians would be anachronistic enough to claim that the first Lockean truth can be equated with some self-evidently ancient hope. Plato and Aristotle criticized democracy for its very tendency to treat all men as equal, although anyone could see that some men were more virtuous and wiser 
than others. Zuckert is absolutely right that one needs a Locke for this ideology to make it look a historical view in the first place.

23. Joseph J. Ellis, American Sphinx: The Character of Thomas Jefferson (New York: Alfred A. Knopf, 1997), 297.

24. Daniel T. Rodgers, "Republicanism: the Career of a Concept," The Journal of American History 79 (June 1992), 14.

25. Johann N. Neem, "American History in a Global Age," History and Theory 50 (Feb. 2011), 41-70, (For quotations, see 53, 56)

26. "Lieberman Urges 'A Place for Faith'," Richmond Times-Dispatch, Aug. 28, 2000 (emphasis added).

27. See Ting-Toomey's innovative "identity negotiation perspective," in Stella Ting-Toomey, Communicating Across Cultures (New York: The Guilford Press, 1999), passim., esp., 29.

28. Quotations, Peter S. Onuf, Jefferson's Empire: The Language of American Nationhood (Charlottesville: University of Virginia Press, 2000), 226n63; The pamphlet is also discussed in Werner Sollors, Beyond Ethnicity: Consent and Descent in American Culture (New York: Oxford University Press, 1986), 175.

29. Jane Sherron De Hart, "Welfare as Identity Politics: Rediscovering Nationalism, Re-viewing the American National Experience, and Recasting the 'Other' in the Post-Cold War United States" in Mark Shackleton and Maarika Toivonen, Roots and Renewal: Writing of Bicentennial Fulbright Professors (Helsinki: Renvall Institute of the University of Helsinki, 2001), 30-44; quotation, 39.

30. Appleby, "Republicanism in Old and New Contexts," 1986, 33. None of this is to claim that history writing could avoid being to some extent political. An illuminating example of fully politicized history writing is Jerome Huyler's Locke in America (1995) with no less a subtitle than The Moral Philosophy of the Founding Era. For Huyler, who has "gotten the whole Locke" and "gotten him right" (ibid., 35) the essential outcome is this: The founders, Jeffersonians and Hamiltonians alike, remained true to the whole Locke, most notably to "Locke's emphasis on the moral worth of productive labor" (ibid., 18). But in striking contrast to this, the rest of American history amounts to a sad departure from its original moral philosophy. Huyler concludes his book with an obscure 1930s pamphlet, Jefferson: the Forgotten Man, to argue that in the American mixed political economy true "Lockean liberalism ...was never permitted to work" (ibid., 308).

31. It was Zuckert himself who once accused John Pocock of omitting the "political context proper" in analyzing one eighteenth-century political debate. As I have attempted to show here, Zuckert's own explication of what truly counts as a political context may seem problematic as well. See Michael P. Zuckert, Natural Rights and the New Republicanism (Princeton: Princeton University Press, 1998), 175.

32. Kuklick, "Myth and Symbol" 1999, 83.

33. Alan Trachtenberg, Brooklyn Bridge: Fact and Symbol, Second Edition (Chicago: University of Chicago Press, 1979), 14.

34. Ibid., p. 12. (See also ibid, 168.)

35. See for example, Maurizio Valsania, The Limits of Optimism: Thomas Jefferson's Dualistic Enlightenment (Charlottesville: University of Virginia Press, 2011).

36. See Lawrence Grossberg's entry on "Cultural Studies" in Wolfgang Donsbach (ed.), The International Encyclopedia of Communication, Vol. 3. (Hoboken, N.J: Wiley-Blackwell, 2008), 1110-1116 (brackets and exclamation marks added).

37. As for further determinations of power, let me add that power can grow and diminish, but in modern democracy the concept rests on a simple reciprocity principle: that the rulers remain democratically responsible to the ruled. To be sure, our constantly growing impact on the rest of nature cannot grant threatened species any judicial, reciprocal powers as arising from some inborn natural rights. This is why power is a moral issue just as much as merely a judicial one.

38. Ralph Ellison, Invisible Man [1947] (New York: Random House, Vintage Books, 1972), 140. 
39. Paul S.Boyer et al., The Enduring Vision: A History of the American People. Fifth Edition (Boston: Houghton Mifflin Company, 2004), 913.

40. Andrew Sullivan, "The President of the United States Shifted the Mainstream in One Interview", Newsweek 21.5. 2012.

41. None of this is to argue against Chafe's commitment to study the Civil Rights Movement from the perspective of social history. See William H. Chafe, "From Community Study to National Politics: How Greensboro, North Carolina Provides a Prism for Understanding Race in America in the 1960s," in Ari Helo (ed.), Communities and Connections: Writings in North American Studies (Helsinki: Renvall Institute, 2007), 19-29; quotations, 19.

\section{ABSTRACTS}

This article suggests that, contrary to a widely shared view among American scholars, a progressive view of history is neither essential nor helpful to historical research in American studies-or in any other academic field.

\section{INDEX}

Keywords: American History, historiography, methodology

\section{AUTHOR}

\section{ARI HELO}

History of Science and Ideas, University of Oulu 